\title{
COMMENTS
}

\section{THE EMERGING CIRCUIT SPLIT OVER SECONDARY MEANING IN TRADE DRESS LAW}

\author{
INGRIDA KARINS BERZINS ${ }^{\dagger}$
}

\section{INTRODUCTION}

Big-city sidewalk vendors have long hawked "Rolex" watches and "Donna Karan" t-shirts. In an upscale twist on the theme, the Wall Street Joumal recently reported that "purse parties," in which hostesses sell knockoff designer goods to their friends, are a hot new trend, albeit with the potential downside of jail time. ${ }^{1}$ Such counterfeits have become a huge business and a major challenge for law enforcement. At a Garment District warehouse in December 2003, New York police netted $\$ 1$ million worth of counterfeit handbags purporting to be made by Louis Vuitton Malletier, Burberry Ltd., Chanel, Inc., and other luxury manufacturers. ${ }^{2}$ For Coach, Inc., a maker of handbags and one of the standbys of the sidewalk scene and purse parties, the story is all too familiar: the company's goods turn up regularly in such stings. ${ }^{3}$

' B.A. 1994, Yale University; M.A.L.D. 2000, The Fletcher School of Law and Diplomacy (Tufts University); J.D. Candidate 2004, University of Pennsylvania. My heartfelt thanks to Professor Herbert F. Schwartz for inspiring this Comment and for reviewing several drafts; to Vincent $\mathrm{N}$. Palladino for his helpful comments; and to University of Pennsylvania Law Review editors Michael Bacchus, Ilana Eisenstein, and Danielle Estrada for their thoughtful guidance. Any remaining errors or omissions are mine alone. This Comment is dedicated to Andris, Lucija, and Kaldis.

' Caitlin Ingrassia, Knockoffs Go Suburban, WALL ST. J., Jan. 16, 2004, at A7.

${ }^{2} \$ 1$ Million in Counterfeit Designer Merchandise is Seized, N.Y. SUN, Dec. 19, 2003, at 3.

${ }^{3}$ For instance, Coach goods turned up in a November 2002 raid in Brooklyn. Lydia Polgreen, Trademark Scheme, N.Y. TimES, Nov. 28, 2002, at B8. In February 2001, yet another seizure of counterfeit Coach handbags led to a successful trademark infringement suit in Coach, Inc. v. We Care Trading Co., No. 99-11672, 2001 U.S. Dist. LEXIS 9879 (S.D.N.Y. July 19, 2001), affd in part and vacated in part, No. 01-7968, 2002 U.S. App. LEXIS 28143 (2d Cir. May 20, 2002). 
To the extent that they care about legal niceties, copycat manufacturers may be relying on the Supreme Court's 2001 observation that "in many instances there is no prohibition against copying goods and products. ... Allowing competitors to copy will have salutary effects in many instances." Yet, the Court also carefully noted that copiers may not infringe recognized intellectual property rights. ${ }^{5}$ Coach handbags, for example, are protected by federal statute and common law governing the use of trade dress, ${ }^{6}$ a subset of trademark law that encompasses both product design and product packaging. The past several years have witnessed evolving legal standards for trade dress protection, offering the prospect of legal redress against the many-headed Hydra of the counterfeit industry.

The Supreme Court's 2000 decision in Wal-Mart Stores, Inc. v. Samara Brothers ${ }^{7}$ was widely expected to fundamentally limit the extent of legal protections for trade dress. For product design, one category of trade dress, the picture indeed looked ominous: the Supreme Court stated that distinctiveness, one of the elements necessary to protect a valid trademark, could no longer be found "inherent," or automatic, for product design simply by virtue of its uniqueness. ${ }^{8}$ Instead, distinctiveness now requires proving that the trade dress has acquired secondary meaning, defined as a connection in consumers' minds between the product and its manufacturer. ${ }^{9}$ To show secondary meaning, the trade dress owner must prove that the trade dress identifies the source of the product to consumers. ${ }^{10}$

Immediately after the case, commentators lamented the "death knell" sounded by the Court for product design trademark owners." Observers feared that, without the possibility of claiming inherent

${ }^{4}$ TrafFix Devices, Inc. v. Mktg. Displays, Inc., 532 U.S. 23, 29 (2001) (citation omitted).

${ }^{5}$ See id. ("In general, unless an intellectual property right such as a patent or copyright protects an item, it will be subject to copying.")

${ }^{6}$ See Coach, 2001 U.S. Dist. LEXIS 9879 , at $* 45-46$ (giving trade dress protection to Coach handbags).

529 U.S. 205 (2000).

${ }^{8} I d$. at 213-14.

${ }^{9} I d$. at 212-13 (describing the use of design features to "signal" to the consumer the identity of the producer).

${ }^{10} I d$. (noting that in product design cases, the "attribution of inherent distinctiveness" derives from "consumer predisposition to equate the feature [whether color, packaging, word marks, or other design feature] with the source").

"Tahj Gomes \& Carla DeSilva, Wal-Mart Stores, Inc. v. Samara Brothers, Inc.: The Supreme Court Steps Back from Two Pesos and Requires Secondary Meaning in All Product Design Trade Dress Cases, 17 SANTA ClaRA COMPUTER \& HIGH TECH. L.J. 365, 370 (2001). 
distinctiveness, product design owners would have little legal protection for their marks because the new requirement of proving acquired distinctiveness was potentially onerous. ${ }^{12}$ By narrowing the scope of trade dress protection in an effort to forestall anticompetitive strike suits, some argued, "Wal-Mart will likely benefit [the] consumer's interests since it promotes competition in the marketplace."13 But for the counterfeit industry, Wal-Mart "could have the unfortunate effect of encouraging the practice of 'knock-offs,' especially in the fashion industry."

While Wal-Mart deprived trade dress of automatic, or inherent, distinctiveness, TrafFix, decided by the Supreme Court a year later, increased the difficulty with which trade dress owners must demonstrate non-functionality. ${ }^{15}$ Although these two cases seemed to indicate that the Supreme Court had significantly raised the bar for product design protection, the Wal-Mart decision has not entirely stemmed the flow of product design claims, nor has it precluded trade dress owners from protecting their products from infringement. In fact, as I will discuss, several trade dress owners have recently adapted to the new requirements set out by Wal-Mart and prevailed against infringers.

This Comment examines recent product design case law to evaluate the effect of Wal-Mart on how secondary meaning can be shown by trade dress owners, identifies which types of trade dress claims are most likely to satisfy the secondary meaning requirement, and describes the growing rift among the circuits in the application of factors that are used to evaluate secondary meaning. This Comment then

${ }^{12}$ See, e.g., Joseph J. Ferretti, Product Design Trade Dress Hits the Wall . . Mart: WalMart v. Samara Brothers, 42 IDEA 417, 449 (2002) (finding that "the Wal-Mart court appears to have ignored the important underlying goals of trademark law: preventing competitors from trading off the goodwill of another and protecting consumers from being confused as to the source or origin of a company's goods or services"); Jeffrey M. Samuels \& Linda B. Samuels, Trade Dress Undressed: Wal-Mart v. Samara, 29 A.I.P.L.A. Q.J. 43, 63 (2001) (noting that Wal-Mart will "render legal protection for new designs ... problematic and will create additional uncertainty in the law").

${ }^{13}$ Antonia L. Sequeira, Recent Case, Wal-Mart Stores, Inc. v. Samara Brothers, 16 BERKELEY TECH. L.J. 251, 260 (2001).

${ }^{14}$ Christina Platt Hillson, Trade Dress Protection: When a Dress is Just a Dress According to the Supreme Court in Wal-Mart Stores, Inc. v. Samara Brothers, 53 BAYLOR L. REv. 461, 487 (2001).

${ }^{15}$ TrafFix Devices, Inc. v. Mktg. Displays, Inc., 532 U.S. 23, 32 (2001). The Court defined a functional feature as one "the exclusive use of [which] would put competitors at a significant non-reputation-related disadvantage." Id. (quoting Qualitex Co. v. Jacobson Prods. Co., 514 U.S. 159, 165 (1995)). The Court further clarified that "a feature is also functional when it is essential to the use or purpose of the device or when it affects the cost or quality of the device." Id. at 33 (citations omitted). 
argues that product design litigation since Wal-Mart reveals a growing gulf among the circuits' evidentiary requirements for proving secondary meaning. In time, it will be necessary for the Supreme Court to answer the question it posed, yet left unanswered, in Wal-Mart: "What must be shown to establish that a product's design is inherently distinctive for purposes of Lanham Act trade-dress protection?" 16

Part I defines trade dress. Part II discusses the elements that must be shown to obtain Lanham Act protection for trade dress. Part III introduces Wal-Mart and the current state of the secondary meaning doctrine, and Part IV examines the effect of Wal-Mart on trade dress law. Part $\mathrm{V}$ discusses the factors that various circuits use to establish secondary meaning, and Part VI surveys recent trade dress litigation that illustrates the current state of the secondary meaning doctrine and indicates the direction in which trade dress litigation appears to be heading.

\section{TRADE DRESS IN THE CONTEXT OF TRADEMARK LAW}

According to a widely cited definition, trade dress "involves the total image of a product and may include features such as size, shape, color or color combinations, texture, graphics, or even particular sales techniques." ${ }^{17}$ Trade dress is a subset of trademark law and is also protected, whether registered or unregistered, by the Lanham Act. ${ }^{18}$ Typically, trade dress litigation is brought under section 43(a) of the Act, which addresses unregistered marks. ${ }^{19}$ The Lanham Act grants trade dress owners "the exclusive right to use the trade dress and the right to prevent confusion of the consuming public in the marketplace."20 Despite the application of these statutory provisions, Congress has not succeeded in passing a federal trademark bill for trade dress. $^{21}$ Instead, trade dress law has common law origins and

${ }^{16}$ Wal-Mart Stores, Inc. v. Samara Bros., 528 U.S. 808, 808 (1999) (granting certiorari).

${ }^{17}$ John H. Harland Co. v. Clark Checks, Inc., 711 F.2d 966, 980 (11th Cir. 1983).

18 The Trademark Act of 1946 (Lanham Act), 15 U.S.C. $\$ \$ 1051-1129$ (2000).

1915 U.S.C. $\$ 1125(2000)$. This is true, for instance, of the three most recent Supreme Court cases discussing trade dress: Two Pesos, Inc. v. Taco Cabana, Inc., 505 U.S. 763, 763 (1992); Wal-Mart, 529 U.S. at 205; and TrafFix, 532 U.S. at 23. In fact, in 1992, the Supreme Court affirmed that section 43(a) of the Lanham Act clearly provides protection for both registered and unregistered trademarks in Two Pesos, 505 U.S. at $765 \mathrm{n} .2$.

${ }^{20}$ See William E. LeVin, Trade Dress Protection $\$ 1: 4$, at 1-10 (1996).

${ }^{21}$ Congress attempted to pass an applicable trademark bill in 1998, A Bill to Amend the Trademark Act of 1946 to Provide Protection for Trade Dress, and for 
continues to be primarily judge-made in the federal courts. ${ }^{22}$ As this Comment will argue, the common law evolution of trade dress law has led to significant variance in how courts define and protect trade dress, and occasionally, the Supreme Court has stepped in to referee.

Trade dress may be divided into two general categories: product packaging and product design. As the Restatement (Third) of Unfair Competition ${ }^{23}$ made clear, trade dress traditionally covered the packaging or labeling of a product, but now can encompass the "overall appearance or image of goods and services." ${ }^{24}$ The extension of trade dress protection to product design is a fairly recent development, ${ }^{25}$ and the courts are still in the process of working out just what kind of protection is available to trade dress owners. The secondary meaning discussion in this Comment illustrates one aspect of trade dress law that has been in flux.

\section{Protecting TRADE DRESS UNDER THE LANHAM ACT}

To recover for trade dress infringement or unfair competition under section 43(a) of the Lanham Act, a plaintiff must prove three elements by a preponderance of the evidence. ${ }^{26}$ First, the plaintiff

Other Purposes, H.R. 3163, 105th Cong. (1998), but it died after a subcommittee hearing.

${ }^{22}$ LEVIN, supra note $20, \$ 1: 4$, at 1-11 (citing L.A. Gear, Inc. v. Thom McAn Shoe Co., 988 F.2d 1117, 1128 (Fed. Cir. 1993)). Indeed, section 43(a) of the Lanham Act is the only section of the Act that specifically mentions trade dress by name, stating that " $[\mathrm{i}] \mathrm{n}$ a civil action for trade dress infringement under this Act for trade dress not registered on the principal register, the person who asserts trade dress protection has the burden of proving that the matter sought to be protected is not functional." 15 U.S.C. $\S 1125(\mathrm{a})(3)(2000)$.

${ }^{23}$ RESTATEMENT (THIRD) OF UNFAIR COMPETITION $\$ 16 \mathrm{cmt}$. A (1993).

${ }^{24}$ Id.; see also J. THOMAS MCCARTHY, MCCARTHY ON TRADEMARKS AND UNFAIR COMPETITION \$ 8.01 [3], at 8-9 (4th ed. 1996) (noting that the "traditional definition of trade dress was limited to the overall appearance of . . packaging[,] ... [and o]ver a period of years, ... expanded to ... include [] the totality of any elements in which a product or service is packaged ... [and] ... to encompass ... the shape and design of the product itself").

${ }^{25}$ While common law protection for product packaging predates 1976 , one commentator believes "the first successful 'product imitation' action brought under section 43 of the Lanham Act" specifically protecting product design to be Truck Equip. Serv. Corp. v. Fruehauf, Corp. (TESCO), 536 F.2d 1210 (8th Cir. 1976). Graeme B. Dinwoodie, Reconceptualizing the Inherent Distinctiveness of Product Design Trade Dress, 75 N.C. L. REv. 471, 478 n.20 (1997) (citing Jessica Litman, Note, The Problem of Functional Features: Trade Dress Infringement Under Section 43(a) of the Lanham Act, 82 CoLUM. L. REV. $77,83(1982))$.

${ }^{26}$ See, e.g., Mktg. Displays, Inc. v. TrafFix Devices, Inc., 200 F.3d 929, 936 (6th Cir. 1999) (stating the burden of proof required), rev'd on other grounds, 532 U.S. 23 (2001). 
must show that the two marks are so similar that there is a likelihood of confusion, which occurs when there is "any word, term, name, symbol, or device, or any combination thereof ... which is likely to cause confusion .... as to the origin, sponsorship, or approval of his or her goods." ${ }^{27}$

The second element the trade dress owner must prove is that "the appropriated features" ${ }^{\prime 2}$ of the trade dress are primarily nonfunctiona $^{29}$ - a burden that is particularly hard to overcome in product design cases, where the physical function of the object and its appearance are by definition intertwined. The Supreme Court, relying on the Restatement (Third) of Unfair Competition, has stated that a design is "functional" if its "'aesthetic value' lies in its ability to 'confer a significant benefit that cannot practically be duplicated by the use of alternative designs." "\$0

The third, and most contentious, element a trade dress owner must establish is that the mark is distinctive. ${ }^{31}$ This requirement can be met in one of two ways. First, the mark may be "inherently distinctive" because it is a particularly unique, and therefore strong, trademark. Under the most widely used taxonomy, trademarks may be

${ }^{27} 15$ U.S.C. $\S 1125(\mathrm{a})(1)$ (A) (2000). This provision applies to unregistered trade dress. The provision applicable to registered trade dress states that infringement of a registered trade dress consists of using in commerce, without the permission of the registrant, "any reproduction, counterfeit, copy, or colorable imitation of a registered mark ... [if] such use is likely to cause confusion, or to cause mistake, or to deceive." 15 U.S.C. $\$ 1114$ (1) (a) (2000).

${ }^{28}$ TrafFix, 200 F.3d at 936.

${ }^{29}$ For registered trade dress, the relevant statutory language is contained in section 2(e) (5) of the Lanham Act (codified at 15 U.S.C. \$ 1052(e)(5) (2000)), which states that a trademark may be refused registration if it "comprises any matter that, as a whole, is functional." For unregistered trade dress, the relevant statutory language is contained in section 43(a)(3) (codified at 15 U.S.C. $\$ 1125$ (a) (3) (2000)), which requires that the person asserting protection of an unregistered trademark bears the "burden of proving... [it] is not functional."

${ }^{30}$ Qualitex Co. v. Jacobson Prods. Co., 514 U.S. 159, 170 (1995) (quoting RESTATEMENT (THIRD) OF UNFAIR COMPETITION $\$ 17 \mathrm{cmt}$ c (1993)). In Qualitex, the Court did ultimately find that the plaintiff could obtain trademark protection for the green-gold color of its ironing pads since the color acted "as a symbol that distinguishes a firm's goods and identifies their source, without serving any other significant function." Id. at 166.

${ }^{31}$ In Wal-Mart, the Supreme Court specified that the distinctiveness requirement is explicit in the Lanham Act only for registered trade dress. For unregistered trademarks and trade dress, distinctiveness is a common law requirement "universally imposed" to prevent "confusion ... as to ... origin." Wal-Mart Stores, Inc. v. Samara Bros., 529 U.S. 205, 210 (2000) (citing the Lanham Act at $\$ 43$ (a) (1)(A), 15 U.S.C. $\$$ 1125 (a)(1)(A) (Supp. V 1994)). 
grouped "in an ascending order which roughly reflects their eligibility to trademark status and the degree of protection accorded[.] [T] hese classes are (1) generic, (2) descriptive, (3) suggestive, and (4) arbitrary or fanciful." ${ }^{32}$ Some examples of marks falling under these categories include: "shredded wheat," a generic mark for shredded wheat cereal ${ }_{33}^{33}$ "Fish-Fri," a descriptive mark for fish batter mix; ${ }^{34}$ "Coppertone," a suggestive mark for sunscreen; $;$ and "Kodak," an arbitrary mark for film and camera products. ${ }^{36}$ Only suggestive, arbitrary, and fanciful marks, "because their intrinsic nature serves to identify a particular source of a product, are deemed inherently distinctive and are entitled to protection." ${ }^{37}$ At the other end of the scale, generic marks may not be protected at all. ${ }^{38}$

Between these two extremes are marks that, though not inherently distinctive, can acquire distinctiveness over time, thereby obtaining trademark protection. For example, descriptive marks are not considered to be inherently distinctive, but as the Supreme Court stated in Two Pesos, Inc. v. Taco Cabana, Inc.," "descriptive marks may acquire the distinctiveness which will allow them to be protected under the [Lanham] Act." ${ }^{40}$ Thus, while inherent distinctiveness is automatically assumed based on the substance of the mark alone, acquired distinctiveness, also called secondary meaning, ${ }^{41}$ must be proven through extrinsic evidence. ${ }^{42}$ The Supreme Court defined secondary meaning as arising when, "in the minds of the public, the primary significance of a [mark] is to identify the source of the product rather than the

${ }^{92}$ Abercrombie \& Fitch Co. v. Hunting World, Inc., 537 F.2d 4, 9 (2d Cir. 1976).

${ }^{33}$ Kellogg Co. v. National Biscuit Co., 305 U.S. 111, 116 (1938).

${ }^{34}$ Zatarains, Inc. v. Oak Grove Smokehouse, Inc., 698 F.2d 786, 796 (5th Cir. 1983).

${ }^{35}$ Douglas Lab. Corp. v. Copper Tan, Inc., 210 F.2d 453, 455 (2d Cir. 1954).

${ }^{36}$ Eastman Kodak Co. v. Weil, 243 N.Y.S. 319, 321 (N.Y. Sup. Ct. 1930).

${ }^{87}$ Two Pesos, Inc. v. Taco Cabana, Inc., 505 U.S. 763, 768 (1992).

${ }^{38}$ See id. at 768 ("[G]eneric marks ... are not registrable as trademarks.").

${ }^{39}$ Id. at 763.

${ }^{40}$ Id. at 769 .

${ }^{41}$ Id.

${ }^{42}$ For a particularly lucid explanation of the difference between inherent and acquired distinctiveness, see Dinwoodie, supra note 25, 485-89. That article explains that inherently distinctive marks enjoy "instant protection" because "inherent distinctiveness can be presumed immediately upon use," $i d$. at 488 , while descriptive marks must establish secondary meaning through "evidence of actual consumer association" and "must await the development of the evidence from which it can be inferred, and thus protection is not available upon first use." Id. at 487-88. 
product itself." ${ }^{43}$ The Second Circuit has found secondary meaning where "'the public is moved in any degree to buy an article because of its source." $"{ }^{4}$

\section{WAL-MART AND THE SECONDARY MEANING DOCTRINE}

In Wal-Mart, the Supreme Court refused to find that trade dress, as it applies to product design, is inherently distinctive. Instead, the Court required the plaintiffs to demonstrate that their product design had acquired secondary meaning. The litigation leading to Wal-Mart arose when Samara Brothers, Inc., a designer of children's "spring/ summer one-piece seersucker outfits decorated with appliqués of hearts, flowers, fruits, and the like," ${ }^{45}$ discovered that its upscale clothing had been copied and was being sold at cut rates by discounters such as Wal-Mart, Kmart, and Caldor. ${ }^{46}$ After settling with the other defendants, Samara sued Wal-Mart Stores, Inc. for, among other claims, infringement of unregistered trade dress under the Lanham Act. ${ }^{47}$

Samara had good reason to be sanguine about its chances to prevail against Wal-Mart. In Two Pesos, the Supreme Court had upheld the trademark rights of a chain of Mexican fast-food restaurants for trade dress described as "a festive eating atmosphere having interior dining and patio areas decorated with artifacts, bright colors, paintings and murals." ${ }^{\text {S4 }}$ Surely this set of characteristics was no more specific and persuasive a type of trade dress than the clearly defined elements of Samara's children's clothing.

Moreover, in Two Pesos, the Court had made two key points on the issue of inherent distinctiveness. First, the Court found that the plaintiff, Two Pesos, Inc. had satisfied the distinctiveness requirement by having its trade dress classified as suggestive, arbitrary, or fancifulthe three categories of trademark that enjoy automatic inherent distinctiveness. ${ }^{49}$ Second, to underscore this point, the Court held

${ }^{43}$ Inwood Labs., Inc. v. Ives Labs., Inc., 456 U.S. 844, 851 n.11 (1982).

${ }^{44}$ Genesee Brewing Co. v. Stroh Brewing Co., 124 F.3d 137, 143 n.4 (2d Cir. 1997) (quoting Paper Cutter, Inc. v. Fay's Drug Co., 900 F.2d 556, 564 (2d Cir. 1990)).

${ }^{45}$ Wal-Mart Stores, Inc. v. Samara Bros., 529 U.S. 205, 207-08 (2000).

46 Id. at 208.

${ }^{47}$ Id.

${ }^{48}$ Two Pesos, Inc. v. Taco Cabana, Inc., 505 U.S. 763, 765 (1992) (quoting Taco Cabana Int'l, Inc. v. Two Pesos, Inc., 932 F.2d 1113, 1117 (5th Cir. 1991)).

${ }^{49} I d$. at 768 . The Fifth Circuit had previously stated that "the jury finding that the trade dress is not merely descriptive [nor functional] means that the dress is arbitrary, 
that "proof of secondary meaning is not required to prevail on a claim under $\S 43$ (a) of the Lanham Act where the trade dress at issue is inherently distinctive." ${ }^{50}$

Relying on Two Pesos, Samara argued that its clothing designs should be "legally protected as distinctive trade dress for purposes of Section 43(a). ${ }^{, 51}$ By so doing, Samara had hoped to satisfy the distinctiveness requirement by demonstrating that its mark was inherently distinctive, without having to present the additional evidence required to prove a secondary meaning analysis.

The Supreme Court, however, disagreed and found that Samara's clothing designs were more analogous to a trademarked color that "could eventually 'come to indicate a product's origin'... [and] could be protected upon a showing of secondary meaning." ${ }^{\text {,52 }}$ The essence of the holding is that, "in an action for infringement of unregistered trade dress under $\S 43(\mathrm{a})$ of the Lanham Act, a product's design is distinctive, and therefore protectable, only upon a showing of secondary meaning." 58

The Court specifically rebutted Samara's efforts to analogize its situation to Two Pesos, in which the trade dress was found to be inherently distinctive:

Two Pesos unquestionably establishes the legal principle that trade dress can be inherently distinctive ... but it does not establish that product-design trade dress can be. Two Pesos is inapposite to our holding here because the trade dress at issue, the décor of a restaurant, seems to us not to constitute product design. It was either product packaging .... or else some tertium quid that is akin to product packaging and has no bearing on the present case.

Many commentators have criticized the peremptory nature of Wal-Mart's classification of Two Pesos' "festive" restaurant decor as product packaging and Samara's children's clothing as product

fanciful, or suggestive. We need not determine which of these three categories properly characterizes the trade dress, because all three entitle Taco Cabana to protection without proof of secondary meaning." Taco Cabana Int'l, 932 F.2d at 1120 n.8.

50 Two Pesos, 505 U.S. at 776.

${ }^{51}$ Wal-Mart, 529 U.S. at 208.

${ }^{52}$ Id. at 212. The Court in Wal-Mart relied on its holding in Qualitex Co. v. Jacobson Products Co., 514 U.S. 159, 162-63 (1995), to reach this conclusion. For a discussion of the Qualitex holding regarding color and distinctiveness, see supra text accompanying note 30 .

${ }^{53}$ Wal-Mart, 529 U.S. at 216.

${ }^{54}$ Id. at 214-15. 
design. ${ }^{5 \overline{3}}$ Yet once trade dress is classified as either product design or product packaging, the consequences, under Wal-Mart, are clear: since "product design almost invariably serves purposes other than source identification," iveness in product design than there is in product packaging.

The Wal-Mart Court pointed out that there was no widely accepted test for inherent distinctiveness and doubted that such a test was even possible, stating "where product design is concerned we have little confidence that a reasonably clear test can be devised." ${ }^{57}$ The Court further rebuffed the suggestion by Samara to adopt the inherent distinctiveness test developed by the Court of Customs and Patent Appeals (the predecessor to the United States Court of Appeals for the Federal Circuit) in Seabrook Foods, Inc. v. Bar-Well Foods, Ltd. ${ }^{58}$ that considered:

whether it was a 'common' basic shape or design, whether it was unique or unusual in a particular field, [and] whether it was a mere refinement of a commonly-adopted and well-known form of ornamentation for a particular class of goods viewed by the public as a dress or ornamentation for the goods. . . .

Finally, the Court stated that "given the unlikelihood of inherently source-identifying design, the game of allowing suit based on alleged inherent distinctiveness seems to us not worth the candle," these trade dress owners could also seek patent or copyright protection for their designs. While this may be true, the Wal-Mart Court was also well aware that design owners would prefer trademark protec$\operatorname{tion}^{61}$ - which is perpetual, so long as the mark is in use-over patent

${ }^{55}$ One article notes that the Two Pesos Court had "treated trade dress as a unitary concept; that is, it made no distinction between product packaging and product design trade dress." Samuels \& Samuels, supra note 12, at 46. This article also notes that, in the years after Two Pesos, courts around the country struggled "to determine if trade dress is a design or packaging." Id. at 59-60; see also Paul A. Briganti, Renovating Taco Cabana: The Lanham Act's Protection of Product Design After Samara, 38 CAL. W. L. REv. 481,504 (2002) (criticizing as unfounded the Court's statements "in conclusory terms that restaurant décor constitutes product packaging").

${ }^{56}$ Wal-Mart, 529 U.S. at 213.

${ }^{57} I d$.

${ }^{58} 568$ F.2d 1342 (C.C.P.A. 1977).

${ }^{59}$ Id. at 1344, quoted in Wal-Mart, 529 U.S. at 214.

${ }^{60}$ Wal-Mart, 529 U.S. at 214.

${ }^{61}$ The Lanham Act provisions discussing trademark registration and unlimited renewal rights are set out in sections 8 and 9 of the Act (codified at 15 U.S.C. $\$ \S 1057-$ $1059(2000))$. For unregistered trademarks, the relevant statutory provision is 15 U.S.C. $\S 1125$ (2000), which is section 43 of the Lanham Act. 
protection $^{62}$ (twenty years from date of filing) or copyright protection ${ }^{63}$ (life of author plus seventy years).

\section{The Consequences of WAL-MART}

Wal-Mart affected the law of product design trade dress in two ways. First, it clarified the distinctiveness requirement for trade dress. Second, it narrowed the scope of protection available and thereby created incentives for trade dress owners to argue that their marks are product packaging rather than product design. Contrary to initial fears expressed at the time of the decision, Wal-Mart does not stand for the proposition that trade dress cannot be protected. Instead, as in the cases discussed below, it has even assisted product design owners to prevail against infringers. Yet the decision has rightly been criticized for confusing as much as clarifying the issue.

\section{A. Critique of Wal-Mart's New Distinctiveness Standard}

Wal-Mart attempted to clarify the law of trade dress by finding that distinctiveness could be established for product design only through a showing of secondary meaning. ${ }^{64}$ Further, the Court maintained the test for secondary meaning that had been set forth in Inwood Laboratories. $^{65}$ Wal-Mart, therefore, was intended to be a straightforward solution to a troubling circuit split. In the period between the 1992 holding in Two Pesos and the 2000 decision in Wal-Mart, courts had found that product design could be inherently distinctive. ${ }^{66}$ Unfortunately,

${ }_{62}^{62} 35$ U.S.C. $\$ 154(\mathrm{a})(2)(2000)$.

${ }^{63} 17$ U.S.C. $\$ 302(2000)$.

${ }^{64}$ See Wal-Mart, 529 U.S. at 216 (holding that a "product's design is distinctive, and therefore protectible, only upon a showing of secondary meaning").

${ }^{65}$ Wal-Mart, 529 U.S. at 211 (quoting Inwood Labs., Inc. v. Ives Labs., Inc., 456 U.S. 844, $851 \mathrm{n.11}(1982)$ ). The Inwood Laboratories test, as described by the Court in Wal-Mart, states that "a mark has acquired distinctiveness, even if it is not inherently distinctive, if it has developed secondary meaning, which occurs when, 'in the minds of the public, the primary significance of a [mark] is to identify the source of the product rather than the product itself." Id.

${ }^{66}$ Some examples of cases from 1992 to 2000 in which courts had found product design to be inherently distinctive include Duraco Products, Inc. v. Joy Plastic Enterprises Ltd., 40 F.3d 1431, 1446-52 (3d Cir. 1994) (holding that, while product configuration could be inherently distinctive under certain circumstances, Duraco's Grecian urnshaped plastic planters were not so "unusual and memorable" as to satisfy this circuit's three-prong test for inherently distinctive product design), and Ashley Fumiture Industries, Inc. v. SanGiacomo N.A., 187 F.3d 363, 366 (4th Cir. 1999) (finding that a "product's configuration qualifies as inherently distinctive trade dress if it is capable of functioning as a designator of an individual source of the product"). 
the trouble was, federal courts were "hopelessly conflicted on what the proper test was for determining whether a product design is inherently distinctive." ${ }^{67}$ There were conflicting inherent distinctiveness tests in use in the Second, Third, Fourth, and Eighth Circuits. ${ }^{68}$ After Wal-Mart, in any trade dress claim involving product design, distinctiveness must be shown through evidence of secondary meaning. ${ }^{69}$ WalMart's bold move to wipe out inherent distinctiveness with respect to product design, however, drew the ire of trademark commentators, who criticized the decision as "ill advised," one which "solved one problem ... [but] a study of its wake reveals twice as many concerns." Another observer considered that the decision was fundamentally flawed as the Court did not answer the question it had posed in granting certiorari, thereby confusing the litigating parties: "[T]he Supreme Court did not hand down a decision explaining 'what must be shown to establish that a product's design is inherently distinctive for purposes of Lanham Act trade dress protection.' Instead, the Court punted." ${ }^{, 2}$ This critique probably explains why Samara, in its brief to the Supreme Court, argued for the Seabrook inherent distinctiveness test, rather than amassing the evidence needed to prove that its clothing designs had acquired secondary meaning. ${ }^{73}$ The plaintiff simply could not have anticipated from the writ granting certiorari that secondary meaning would replace inherent distinctiveness as the central issue in the case.

A second criticism levied at Wal-Mart's efforts to clarify the law is that eliminating inherent distinctiveness essentially permits "competitors [to] freely copy unique designs early in the product's life, thus preventing the establishment of secondary meaning." ${ }^{.74}$ The case law examined in the next Section certainly bears this criticism out. In all the cases where secondary meaning was found, the product designs in question had been in use for years, if not decades, leaving unanswered

${ }^{67}$ Samuels \& Samuels, supra note 12, at 51.

${ }^{63}$ See id. at 48-51 (describing the conflicting tests for inherent distinctiveness developed in Ashley Furniture, 187 F.3d at 366; Knitwaves, Inc. v. Lollytags Ltd., 71 F.3d 996 (2d Cir. 1995); Stuart Hall Co. v. Ampad Corp., 51 F.3d 780 (8th Cir. 1995); Duraco Products, 40 F.3d at 1446-52).

69 Wal-Mart, 529 U.S. at 216.

${ }^{70}$ Samuels \& Samuels, supra note 12, at 63.

${ }^{7}$ Briganti, supra note 55, at 505.

${ }^{72}$ Ferretti, supra note 12, at 437 (quoting Wal-Mart, 529 U.S. at 213-14) (emphasis added).

73 Wal-Mart, 529 U.S. at 213-14.

${ }^{74}$ Ferretti, supra note 12 , at 418. 
the question of what a litigant launching a new product can or should do to protect its trade dress in a product design.

\section{B. Narrowing the Scope of Trade Dress Protections}

The two ways in which Wal-Mart has narrowed the scope of protection for trade dress are (1) it forced courts to distinguish between product packaging and product design, since their definitions are essential to applying the correct analysis for distinctiveness, and (2) it recommended that lower courts should be conservative in making this determination, thereby automatically limiting the number of products likely to earn the now-desirable distinction of product packaging over product design. Without explaining the need for such caution, the Wal-Mart decision merely stated that other courts should "err on the side of caution and classify ambiguous trade dress as product design, thereby requiring secondary meaning."

These changes have led some commentators to point out that WalMart has introduced a new level of complexity into trade dress design, since the "application of different tests to packaging and design cases is impractical and unwarranted." Another commentator observed that forcing a choice between product packaging and product design will again ultimately lead to a circuit split, since "lower courts again will develop conflicting tests. It is therefore possible that varying results will be seen on similar types of trade dress, depending on each circuit's test." ${ }^{\text {,78 }}$

In Wal-Mart itself, the Court acknowledged the potential problems of forcing courts to distinguish product packaging from product design:

There will indeed be some hard cases at the margin: a classic glass CocaCola bottle, for instance, may constitute packaging for those consumers who drink the Coke and then discard the bottle, but may constitute the product itself for those consumers who are bottle collectors, or part of the product itself for those consumers who buy Coke in the classic glass

${ }^{75}$ One possible response by trade dress owners can be seen in their sharply rising number of Lanham Act registrations since 2000. “[F]ederal trade dress registration makes any validity challenge an uphill battle for competitors that choose to copy distinctive dress," so registration is a first step toward protection of new trade dress. William Levin, A Rush to Register Trade Dress, NAT'L L.J., Jan. 8, 2001, at B7.

${ }^{76}$ Wal-Mart, 529 U.S. at 215.

${ }^{77}$ Samuels \& Samuels, supra note 12, at 63.

${ }^{78}$ Ferretti, supra note 12, at 444. 
bottle, rather than a can, because they think it more stylish to drink from the former.

The Court did not attempt to solve this conundrum, stating only that it believed that "the frequency and the difficulty of having to distinguish between product design and product packaging will be much less than the frequency and the difficulty of having to decide when a product is inherently distinctive." ${ }^{80}$ Whether this has proven true is debatable. One could look at a trademark author's efforts to graphically clarify the confusion. In attempting to distinguish between "WalMart product design" and "Two Pesos trade dress," the author has placed restaurant and retail décor squarely in the Two Pesos category of trade dress that could be found to be inherently distinctive. ${ }^{81}$

However, a 2001 case in the Ninth Circuit belies such an easy characterization. In Clicks Billiards, Inc. v. Sixshooters, Inc., ${ }^{82}$ the plaintiff owner of a chain of pool halls, sued a competitor for trade dress infringement for copying his halls' unique décor. ${ }^{83}$ While this fact pattern might seem reminiscent of Two Pesos, the similarities stop there because the court did not follow the Wal-Mart characterization of Two Pesos restaurant décor as product packaging or "some tertium quid that is akin to product packaging" ${ }^{\prime 84}$ (either of which could be inherently distinctive). Instead, the Ninth Circuit turned without comment to a discussion of whether the pool hall décor had acquired secondary meaning-without discussing inherent distinctiveness at all. ${ }^{85}$ The plaintiffs ultimately prevailed, but not without having to do the heavy evidentiary lifting needed to show secondary meaning, including introducing consumer surveys and extensive testimony evidence of copying. ${ }^{86}$

${ }^{79}$ Wal-Mart, 529 U.S. at 215.

${ }^{80}$ Id.

${ }^{81}$ Thomas P. ARden, Protection of NONTRAdITIONAL MARKs: Trademark Rights In SOUNDS, SCENTS, COLORS, MOTIONS AND PRODUCT DESIGN IN THE U.S. 51 (2000).

251 F.3d 1252 (9th Cir. 2001).

${ }^{83} I d$. at 1256. The décor is described at length in the decision and includes the floral carpet, mahogany wood, lighting fixtures, tile, signs, drinks rails, layout, color scheme, juke boxes, type of trash cans, and video games. Id. at 1256-57.

${ }^{84}$ Wal-Mart, 529 U.S. at 215.

${ }^{85}$ Clicks Billiards, 251 F.3d at 1262-64. One possible explanation for this is a strategic decision on the part of Clicks Billiards, Inc., which had "not claimed that its trade dress is inherently distinctive, only that it has acquired secondary meaning." Id. at $1258 \mathrm{n} .1$.

${ }^{86}$ Id. at $1262-64$. 
Surveying recent cases, however, we find that less appears to turn on the product design-product packaging axis than might have been expected. After Wal-Mart, courts have generally devoted little or no time to analyzing whether the trade dress in question is product design or product packaging. For instance, in Coach, Inc. v. We Care Trading Co., ${ }^{87}$ a successful product design case, the discussion of secondary meaning does not even mention the possibility that the plaintiff might try to characterize the handbags' features as product packaging. ${ }^{88}$ Similarly, Herman Miller, Inc. v. Palazzetti Imports $\mathcal{E}$ Exports, Inc., ${ }^{89}$ a successful furniture design case, quickly disposed of the product design-product packaging issue. ${ }^{90}$ In a third case (in which the trade dress owner lost), David White Instruments, L.L.C. v. TLZ, Inc., ${ }^{91}$ the court somewhat confusingly referred to the "design or dress" of the product, but applied the product design analysis of secondary meaning in any event. ${ }^{92}$

Perhaps one exception to the general brevity on the product design-product packaging issue can be found in Yankee Candle Co. v. Bridgewater Candle Co. ${ }^{93}$ in which the plaintiff argued (unsuccessfully) that the shelving, labels, and catalog, all "trappings associated with the sale of the candle," were either product packaging or a "tertium quid" analogous to product packaging. ${ }^{94}$ The court was puzzled by what it termed a "combination trade dress claim" of such disparate elements, but fell back on the Supreme Court's advice in Wal-Mart to "err on the side of caution" in doubtful cases: "We follow that advice here. To prevail on its combination claim, Yankee must show that its trade dress has acquired secondary meaning. ${ }^{, 95}$

${ }^{87}$ No. 99-11672, 2001 U.S. Dist. LEXIS 9879, at *1 (S.D.N.Y. July 18, 2001), aff d, No. 01-7968, 2002 U.S. App. LEXIS 13568 (2d Cir. May 20, 2002); see also infra Part VI.B.2. (providing a more extensive discussion of Coach).

${ }^{88} 2001$ U.S. Dist. LEXIS 9879 , at $* 21-22$ (discussing secondary meaning in the context of trade dress only).

${ }^{89} 270$ F.3d 298 (6th Cir. 2001).

${ }^{90}$ See id. at 310 (stating that there was no ambiguity about how to characterize the furniture at issue: "This is not a hard case .... Herman Miller's trade dress claim regarding the Eames lounge chair and ottoman are based on product design and cannot be confused with product packaging").

${ }_{91}$ No. 2-7156, 2002 U.S. Dist. LEXIS 23410 (N.D. Ill. Nov. 25, 2002).

Id. at *12.

${ }^{99} 259$ F.3d 25 (1st Cir. 2001); see infra notes 116-123 and accompanying text (discussing the reasons that Yankee Candle failed the secondary meaning inquiry).

94 259 F.3d at 40.

${ }^{95}$ Id. at 41 (citing Wal-Mart Stores, Inc. v. Samara Bros., 529 U.S. 205, 215 (2000)). 
From these cases, it appears that Wal-Mart's instructions to err on the side of product design have had their effect not only in cases in which a single aspect of a product is in question, but also those in which, arguably, one of several elements might be found to be product packaging. Instead, the product design label has been attached to the whole combination.

\section{THE SECONDARY MEANING FACTORS}

The Wal-Mart Court narrowed the scope of protection for trade dress owners by holding that they were obliged to prove secondary meaning. The Court, however, did not explicitly state how secondary meaning was to be ascertained. ${ }^{96}$ Determining secondary meaning is, as the Restatement (Third) of Unfair Competition explains, "a question of fact, with the burden of proof on the person claiming rights in the designation." ${ }^{97}$ The Lanham Act does not use the phrase "secondary meaning," stating instead that such acquired product identification has occurred when a mark "has become distinctive of the applicant's goods in commerce." ${ }^{98}$ This distinctiveness is one of the requirements to prove likelihood of confusion for both a registered and unregistered trademark, without which there would be no protection available for trademarks or trade dress. ${ }^{99}$

Since the Lanham Act does not specify a statutory test, it has been left to the courts to define the kinds of evidence necessary to establish secondary meaning. In its discussion of distinctiveness and secondary meaning, Wal-Mart made no specific reference to the common law test for secondary meaning, ${ }^{100}$ an omission perhaps explained by the fact that courts have widely employed the secondary meaning factors

${ }^{96}$ See supra Part IV (discussing the effect of Wal-Mart on the secondary meaning doctrine). In TrafFix Devices, Inc. v. Marketing Displays, Inc., a product design case that came before the Supreme Court in the term following Wal-Mart, the plaintiff's failure to establish nonfunctionality meant that the issue of secondary meaning was never reached. See 532 U.S. 23, 33 (2001) ("Functionality having been established, whether MDI's dual-spring design has acquired secondary meaning need not be considered.").

97 RESTATEMENT (THIRD) OF UNFAIR COMPETITION $\$ 13 \mathrm{cmt}$. e (1995); see also Suzanne R. Chauvin \& Nancy A. Warnement, Pleading and Proving the Claim, in Litigating Trademark, Trade DRess, and Unfair Competition CaSes 9, 15 (ALIABA Comm. on Continuing Prof'l Educ. ed., 2002) (reporting that the determination of acquired secondary meaning is "a question of fact").

98 Lanham Act, 15 U.S.C. \$ $1052(\mathrm{f})$ (2000).

99 See Wal-Mart, 529 U.S. at 210 (discussing the distinctiveness requirement under the Lanham Act as explicit in the case of registered trademarks and implicit for unregistered trademarks).

${ }^{100}$ See id. at 210-13 (discussing distinctiveness and secondary meaning). 
for many years. ${ }^{101}$ In spite of the long history of common law definitions of secondary meaning, disparate approaches to secondary meaning among circuit courts have left the exact criteria in doubt. Indeed, the survey below of recent secondary meaning litigation reveals that circuits vary both in the types of factors considered and in the depth of evidentiary support required.

An early articulation of an exhaustive secondary meaning test is found in Echo Travel, Inc. v. Travel Associates ${ }^{102}$ in which the Seventh Circuit articulated foundational types of evidence probative of secondary meaning:

Direct Evidence

(a) direct consumer testimony

(b) consumer surveys

Circumstantial Evidence

(c) exclusivity, length, and manner of use

(d) amount and manner of advertising

(e) amount of sales and number of customers

(f) established place in the market

(g) proof of intentional copying.

The tests or sets of factors used to evaluate secondary meaning in the other circuits are all variations on this basic theme. ${ }^{104}$ Indeed, the Sixth Circuit employs an identical seven-factor test. ${ }^{105}$ Likewise, the First Circuit uses a seven-factor test to evaluate whether "vigorous evidentiary requirements" for secondary meaning have been satisfied. ${ }^{106}$

The Second Circuit uses a somewhat modified version of the factors used in the Sixth and Seventh Circuits, considering with approximately equal weight the following six factors:

(1) advertising expenditures,

(2) consumer studies linking the mark to a source,

(3) unsolicited media coverage of the product,

${ }^{101}$ See infra Appendix (comparing the common law secondary meaning factors considered by the circuits).

${ }^{102} 870$ F.2d 1264 (7th Cir. 1989).

${ }^{109}$ Id. at 1267.

${ }^{104}$ For a discussion of how secondary meaning factors are used directly and indirectly by the courts to "infer consumer association," see Dinwoodie, supra note 25 , at 487-88 \& n.52.

${ }^{105}$ Herman Miller, Inc. v. Palazzetti Imps. \& Exps., Inc., 270 F.3d 298, $311-12$ (6th Cir. 2001).

${ }^{106}$ See Yankee Candle Co. v. Bridgewater Candle Co., 259 F.3d 25, 43-45 (1st Cir. 2001) (describing the secondary meaning factors and attributing them to Boston Beer Co. v. Slesar Bros. Brewing Co., 9 F.3d 175, 181 (1st Cir. 1993), I.P. Lund Trading v. Kohler Co., 163 F.3d 27, 42 (lst Cir. 1998), both of which predate Wal-Mart). 
(4) sales success,

(5) attempts to plagiarize the mark, and

(6) length and exclusivity of the mark's use. ${ }^{107}$

The Second Circuit's test suggests a predilection for finding secondary meaning in products that have been successful in the marketplace and that have gained popular recognition in the press. The Second Circuit appears to be the only circuit to consider "unsolicited media coverage" as probative of secondary meaning. ${ }^{108}$

In contrast to the other circuits, which favor six- or seven-factor tests, the Tenth Circuit cites a brief list of secondary meaning factors including "(1) a history of successful sales; (2) evidence of intentional copying[; . . . and (3) long use of the ... trade dress." ity of the list should not be taken to indicate that the Tenth Circuit is more permissive in its interpretation of secondary meaning requirements than other circuits. To the contrary, because this circuit applies a narrow interpretation to the few factors it does consider when making a determination of secondary meaning, the end result is that trade dress owners litigating in the Tenth Circuit may have a harder time proving secondary meaning than they would elsewhere. ${ }^{110}$

Of the circuits that have engaged in a discussion of secondary meaning, the Ninth Circuit has taken perhaps the most lenient approach. The court found a "triable issue of fact" in a recent case in which only two types of evidence-survey evidence and proof of copying-were introduced to support a claim of secondary meaning. ${ }^{11}$ Moreover, the court found that, "in appropriate circumstances, deliberate copying may suffice to support an inference of secondary meaning."

${ }^{107}$ Coach, Inc. v. We Care Trading Co., No 99-11672, 2001 U.S. Dist. LEXIS 9879, at $* 21-22$ (S.D.N.Y. July 18, 2001) (attributing the factors used in determining secondary meaning to Genesee Brewing Co. v. Stroh Brewing Co., 124 F.3d 137, 143 n.4 (2d Cir. 1997)).

${ }^{108}$ Id. at *21-22.

${ }^{109}$ Sally Beauty Co. v. Beautyco, Inc., 304 F.3d 964, 978 (10th Cir. 2002).

${ }^{110}$ For instance, in comparison with some of the other circuits, this court gives but little weight to sales volume. See id. at 978 (noting that the Sixth and Third Circuits do consider sales volume as part of a secondary meaning analysis). Further, the Tenth Circuit places a restriction on the use of "long use of the trade dress," finding that long use, without a finding of exclusivity, is immaterial to a finding of secondary meaning. See id. at 978 n.4 (attributing the Tenth Circuit's exclusivity requirement to J.M. Huber Corp. v. Lowery Wellheads, Inc., 778 F.2d 1467, 1470 (10th Cir. 1985); the Lanham Act, 15 U.S.C. $\S 1052$ (f) (2000)).

${ }^{111}$ Clicks Billiards, Inc. v. Sixshooters, Inc., 251 F.3d 1252, 1263-64 (9th Cir. 2001).

112 Id. at 1264. 
As this review suggests, the evidentiary requirements to prove secondary meaning are highly court-specific; the factors that may be dispositive in one circuit will not necessarily prove persuasive in another. ${ }^{113}$ But now that the Supreme Court has placed increased importance on secondary meaning, it may be necessary for the Court to create a unified evidentiary standard for how secondary meaning can be established. In the meantime, however, circuits continue using their own standards that, despite their variation, allow some product design owners to prove that their mark has acquired secondary meaning.

\section{SECONDARY MEANING IN ACTION: RECENT LITIGATION}

Recent case law shows that, when courts apply the secondary meaning factors, outcomes are quite varied. In some cases, the protection accorded or denied to trade dress seems to follow predictably from the application of the secondary meaning test to the fact pattern; in other cases, the court seems to have made more of a stretch to achieve its results.

\section{A. When Secondary Meaning Is Not Found}

While this Comment highlights how some product design owners have successfully adapted to the more rigid requirements for secondary meaning since Wal-Mart, it would be misleading to suggest that most product design owners succeed. While I am not aware of any empirical studies quantifying the failure rate of product design cases since 2000 , successful cases appear to be few and far between. ${ }^{114}$

In recent cases in which trade dress owners have tried, and failed, to prove secondary meaning, the judicial opinions cite a variety of shortcomings. Two stand out in particular: poor evidence and a poor definition of the trade dress at issue.

${ }^{113}$ For a detailed discussion of secondary meaning factors and variation among the circuits, see RESTATEMENT (THIRD) OF UNFAIR COMPETITION $\$ 13$, Reporters' Note to cmt. e (1995).

${ }^{114}$ For instance, of the four "successful" product design cases discussed in this Comment, only two, Coach, Inc. v. We Care Trading Co., No 99-11672, 2001 U.S. Dist. LEXIS 9879, at *21-22 (S.D.N.Y. July 18, 2001), and Herman Miller, Inc. v. Palazzetti Imports $\mathfrak{E}$ Exports, Inc., 270 F.3d 298, 311-12 (6th Cir. 2001), are explicitly about product design. Further, a search of primary materials and secondary sources found few similarly successful cases. 
1. A Lack of Survey Evidence Defeats Claims: Yankee Candle Co. $v$. Bridgewater Candle Co. and David White Instruments, LLC v. TLZ, Inc.

Courts have denied trade dress protection when there is a lack of "direct evidence of secondary meaning, such as consumer surveys or testimony," sufficient to demonstrate secondary meaning." kee Candle Co. v. Bridgewater Candle Co., the plaintiff failed to convince the court that the trade dress of its scented candles was product packaging and not product design. Yankee Candle Co. was therefore forced to attempt to fulfill the First Circuit's strict version of the secondary meaning test. ${ }^{117}$

Yankee Candle concerned a complaint brought by a manufacturer against a competitor for infringing its trade dress by copying a method of displaying the candles, the "overall 'look and feel' of Yankee's Housewarmer line of candles," and the layout of Yankee's catalog. ${ }^{118}$ This is one of the few trade dress cases in which the plaintiff tried to circumvent the onerous secondary meaning test by asserting that its trade dress was product packaging. ${ }^{119}$ Further, Yankee argued that, since each of the trade dress elements originated in "arbitrary" choices, its trade dress should be deemed inherently distinctive. ${ }^{120}$

The district court held that Yankee fell "far short" of the evidentiary requirements by failing to introduce any survey evidence, which the First Circuit terms the "'preferred' manner of demonstrating secondary meaning." 121 This failing could not be remedied by Yankee's extensive circumstantial evidence of secondary meaning, including proof that the candles had been marketed since 1985, data showing

${ }^{115}$ Judge Applies Wal-Mart in Rejecting Trade Dress Claims for Medical Equipment: Continental Lab. Prods. v. Medax Int'l, 7 ANDREwS INTELL. PROP. LITIG. REP. 12 (2000) (summarizing holding denying trademark infringement claim of a manufacturer of medical equipment against an admitted copier).

${ }^{116}$ Court Extinguishes Most of Candle Company's Copyright, Trade Dress Suit: Yankee Candle Co. v. Bridgewater Candle Co., 24 ANDREwS INTELL. ProP. LiTIG. REP. 6 (2000) (summarizing case denying infringement claims of a scented candle maker).

${ }^{117}$ Yankee Candle Co. v. Bridgewater Candle Co., 259 F.3d 25, 39 (1st Cir. 2001).

118 Id. at $38-39$.

119 Id. at 40.

${ }^{120}$ Id:; see also supra text accompanying notes 32-37 (describing the standard for inherent distinctiveness as including "arbitrary" marks).

${ }^{121}$ Yankee Candle, 259 F.3d at 38-39 (citing Boston Beer Co. v. Slesar Bros. Brewing Co., 9 F.3d 175, 182 (1st Cir. 1993)). 
substantial advertising outlays, sales figures demonstrating market success, and proof of intentional copying. ${ }^{122}$

To the definite disadvantage of the product design owner in this case, the First Circuit applied the narrowest possible construction to both elements needed to show distinctiveness. First, finding that Yankee Candle's trade dress was on the border between product design and product packaging, the court applied Wal-Mart's default rule that resolves such doubt in favor of product design. Second, the court applied the secondary meaning factors and found that the lack of survey evidence was fatal to finding secondary meaning. ${ }^{123}$

In another case with a similar outcome, David White Instruments, $L L C$ v. TLZ, Inc., ${ }^{124}$ David White argued that TLZ had infringed on novel and non-functional aspects of its patent, particularly the product's physical appearance and design. ${ }^{125}$ Essentially bypassing an analysis of the plaintiff's definition of its trade dress as either product design or product packaging, ${ }^{126}$ the court turned directly to an analysis of the secondary meaning factors: "direct consumer testimony, consumer surveys, length and manner of use, amount and manner of advertising, volume of sales, place in the market and proof of intentional copying." $" 127$

Upon examining the evidence presented, the court found that the plaintiff failed, at least in part, on two of these factors. The plaintiff did not produce "any specific customer surveys" to substantiate its testimony that the David White product line enjoyed broad recognition among its customers, ${ }^{128}$ and its advertising "arguably" promoted "the functional features of the product as opposed to its distinctive trade dress." ${ }^{129}$ While David White did show evidence of substantial, longtime sales and revenues and a "long-standing reputation for

${ }^{122}$ Id. at $44-45$.

${ }^{123}$ Id. at 43.

${ }^{124}$ No. 02-7156, 2002 U.S. Dist. LEXIS 23410 (E.D. Ill. Nov. 25, 2002).

${ }^{25} I d$. at *7-8 (describing the trade dress features as “(1)the 'rounded-delta' level vial recess; (2) the raised semi-cylindrical midsection; (3) the proximal body member with a flat top, a flat bottom and rounded sides; and (4) the overall proportions and relationships of the components").

${ }^{126}$ Id. at $* 11-12$.

${ }^{127} I d$. at *12 (quoting the original source of the factors, Spraying Systems Co. v. Delavan, Inc., 975 F.2d 387, 393 (7th Cir. 1992) and a subsequent use of them, Bretford Mfg., Inc. v. Smith System Mfg. Co., 116 F. Supp. 2d 951, 956 (N.D. Ill. 2000)).

${ }^{128} I d$.

129 Id. at *13. 
manufacturing reliable, high-quality instruments," ${ }^{130}$ the court did not determine whether or not secondary meaning was satisfied. Instead, the court sidestepped the issue, concluding that, "even assuming that this was sufficient to establish secondary meaning, plaintiff has failed to demonstrate a likelihood of success on the issue of customer confusion." $"$ 131

Yankee Candle or David White might have had a very different reception in other, more lenient, circuits, such as the Ninth Circuit, in which a trade dress claim was successful even though the plaintiff provided only a customer survey (admitted to be "of little or no value") and circumstantial evidence of copying to prove secondary meaning. ${ }^{132}$ Clearly, the survey evidence requirement is inconsistently interpreted and applied across various circuits.

2. Failing to Define the Elements of Trade Dress:

Yurman Design, Inc. v. PAJ, Inc.

The Second Circuit in Yurman Design, Inc. v. PAJ, Inc. ${ }^{133}$ failed to reach a detailed secondary meaning discussion because the court was dissatisfied with the plaintiff's definition of its trade dress. ${ }^{134}$ Yurman Design, Inc., designed and manufactured jewelry with copyrighted designs, based on a common motif of twisted cables and gemstones. ${ }^{195}$ The jewelry had been manufactured and widely distributed since 1982. ${ }^{136}$ In 1998, PAJ, Inc., a competitor, began manufacturing copies of Yurman designs, and litigation for copyright and Lanham Act violations ensued. ${ }^{137}$ Despite the jury's finding that 'Yurman's trade dress was distinctive as to the jewelry's source, and that twenty PAJ bracelets, earrings, and rings infringed the trade dress because they were likely

${ }^{130} I d$.

${ }^{191}$ Id. at *13-14.

${ }^{132}$ See Clicks Billiards, Inc. v. Sixshooters, Inc., 251 F.3d 1252, 1263-64 (9th Cir. 2001) (reconciling the weak customer survey with more persuasive circumstantial evidence). In contrast, in a Sixth Circuit case in which the owner had presented no survey evidence at all, the court stated that "[s]urvey evidence is not the only relevant evidence" to support a finding of secondary meaning for product design trade dress. Herman Miller, Inc. v. Palazzetti Imps. \& Exps., Inc., 270 F.3d 298, 312 (6th Cir. 2001) (citing Sugar Busters LLC v. Brennan, 177 F.3d 258, 269 (5th Cir. 1999)).

${ }^{193} 262$ F.3d 101 (2d Cir. 2001).

${ }^{134} I d$. at $117-18$.

${ }^{135} I d$. at 107.

${ }^{136} I d$.

${ }^{137}$ Id. at 107-08. 
to cause confusion concerning the source of PAJ's jewelry," ${ }^{138}$ the Second Circuit reversed. ${ }^{199}$

The chief weakness in Yurman Design's trade dress claim, discussed at some length in the court's opinion, was that "Yurman itself ha[d] never identified the elements that ma[d]e up its trade dress." ${ }^{140}$ Ironically, the court itself had no trouble coming up with a clear definition of Yurman Design's trade dress: "a structural, almost industrial motif of twisted multi-strand cable, executed with a polished and elegant finish, and set off by gemstones."141 But the company's own vague definition of its trade dress, "the artistic combination of cable [jewelry] with other elements," proved fatal to Yurman Design's trade dress claim. ${ }^{142}$

Yurman Design's omission was particularly unfortunate because two other cases decided at roughly the same time, on similar facts, avoided this pitfall. Herman Miller (argued before the Sixth Circuit in November 2000, three months prior to Yurman Design, but decided in October 2001, three months after Yurman Design) listed nine protectable elements of its lounge chair and essentially bombarded the court with factual evidence to support these assertions. ${ }^{143}$ Similarly, the plaintiff in Coach (argued and decided in the Southern District of New York in July 2001) concretely defined its trade dress and successfully supported that definition with empirical evidence. ${ }^{144}$ Given these parallel cases, it would be fair to surmise that the outcome of Yurman Design was due, at least in part, to poor advice from counsel in presenting the trade dress claim.

\section{B. Successful Efforts to Prove Secondary Meaning}

The cases discussed above illustrate the burden borne by product design owners, who must not only clearly state their trade dress by successfully describing visual objects in words, but must also present

${ }^{138}$ Id.

139 Id. at 107.

${ }^{140}$ Id. at 114 .

${ }^{141}$ Id.

${ }^{142} I d$. at 117 (alteration in original).

${ }^{143}$ Herman Miller, Inc. v. Palazzetti Imps. \& Exps., Inc., 270 F.3d 298, 302 (6th Cir. 2001). The court notes that Herman Miller produced "over five hundred pages" of descriptions of the chair contained in various publications and in affidavits of design experts. Id. at 302-03.

${ }^{144}$ Coach, Inc. v. We Care Trading Co., No. 99-11672, 2001 U.S. Dist. LEXIS 9879, at *3-7 (S.D.N.Y. July 18, 2001). 
adequate evidence to prove to the courts that they have skirted the functionality minefield and have shown the clear link in consumers' minds between their product and its source. The outcomes in these and other cases show that this dual exercise is not always an easy one and that trade dress owners will often be disappointed.

Yet, as will be discussed in this Section, there are a few recent cases in which plaintiffs have successfully proven that the design elements of their products have acquired secondary meaning. Two of the most notable examples include Herman Miller ${ }^{145}$ and Coach. ${ }^{146}$ These and other cases show that, while trademark protection may be difficult to attain for trade dress owners faced with the burden of establishing secondary meaning, it is not an impossibility.

Successful or not, recent trademark litigation in the area of product design illustrates that Wal-Mart is having less of a dampening impact than observers had initially feared. The very fact that trade dress owners continue to argue secondary meaning defies the Court's pronouncement in Wal-Mart that "product design almost invariably serves purposes other than source identification." ${ }^{147}$ As the following cases illustrate, some litigants have indeed shown that even if this were true, their product also has a source-identifying function, since they have successfully proven secondary meaning.

1. Abundant Evidence Supports a Claim: Herman Miller, Inc. $v$. Palazzetti Imports Eं Exports, Inc.

This litigation concerns the famous Eames lounge chair and ottoman, designed in 1956 by Charles and Ray Eames and produced exclusively and continuously since that time by licensee Herman Miller, Inc. ${ }^{148}$ In 1995, Herman Miller sued Palazzetti Imports \& Exports, Inc., a New York manufacturer of reproduction furniture, for trademark and trade dress infringement caused by advertising and selling an "Eames chair and ottoman" without clearly stating that its product was a reproduction unaffiliated with Herman Miller. ${ }^{149}$

${ }^{145}$ Herman Miller, 270 F.3d 298 (6th Cir. 2001).

${ }^{146}$ See No. 01-7968, 2002 U.S. App. LEXIS 13568 (2d Cir. May 20, 2002) (affirming and vacating without published opinion), cert. denied, 537 U.S. 1108 (2003). The Second Circuit's decision is reported in full in an unpublished opinion found at Nos. 017968, 01-9162, 2002 U.S. App. LEXIS 28143 (2d Cir. May 20, 2002). Further citations to the Second Circuit's decision will refer to this unpublished opinion.

${ }^{147}$ Wal-Mart Stores, Inc. v. Samara Bros., 529 U.S. 205, 213 (2000).

148 Herman Miller, 270 F.3d at 301-02.

${ }^{149}$ Id. at 305-06. 
The Sixth Circuit's holding in this case is particularly relevant to my examination of secondary meaning because it is detailed in the court's discussion of recent changes in trade dress law. The court stated that Wal-Mart clarified and improved "the protectability analysis in a trade dress claim based on product design." In the period between the 1992 Two Pesos holding that trade dress could be inherently distinctive and the 2000 Wal-Mart ruling that product design demanded a showing of secondary meaning, the circuits had been split over which test should be applied to which type of trade dress. ${ }^{151}$ The Sixth Circuit found that the Eames chair was unambiguously product design, not product packaging, and therefore rejected the lower court's discussion of inherent distinctiveness in favor of an analysis of whether the chair had acquired secondary meaning. ${ }^{152}$

The Sixth Circuit's analysis refers to a set of seven factors articulated by TrafFix Devices, Inc. v. Marketing Displays, Inc. ${ }^{15.9}$ as a "test" for secondary meaning. ${ }^{154}$ This test, later applied in Herman Miller, has no statutory basis; instead, it is another expression of the judicially created law in this area. Perhaps, the term "test" was merely a semantic slip, since the court was careful to note that "[n]o single factor is determinative and every one need not be proven." 155 Whatever the status of these factors, the Sixth Circuit found that Herman Miller established secondary meaning by presenting evidence sufficient to satisfy six of the seven secondary meaning factors employed by the Sixth Circuit. $^{156}$ The only factor for which Herman Miller presented no evidence was that of consumer surveys. ${ }^{157}$ The court gave approximately equal weight to all the satisfied elements, ${ }^{158}$ and in so doing, showed

150 Id. at 308 .

${ }^{151} I d$. at $309-11$

${ }^{152} I d$. at 310 .

${ }^{159} 200$ F.3d 929, 937 (6th Cir. 1999), rev'd, 532 U.S. 23 (2001).

${ }^{154}$ Herman Miller, 270 F.3d at 311.

${ }^{155}$ Id. at 312 . This statement may indicate that the decision does not have the mandatory quality of a "test." An alternate explanation might be that the Herman Miller court considered the seven factors to be so well established in the common law that they had attained "test" status.

${ }^{156}$ Id. at 314-16 (quoting TrafFix, 200 F.3d at 937). In TrafFix, the Sixth Circuit held that the plaintiff manufacturer of traffic sign stands had established secondary meaning for its product design (for which it held an expired patent), but the Supreme Court subsequently reversed on a finding of functionality. TrafFix Devices, Inc. v. Mktg Displays, Inc., 532 U.S. 23, 35 (2001).

${ }^{157}$ Herman Miller, 270 F.3d at 315.

${ }^{158}$ For a discussion of evidence presented for each of the elements, see id. at 31214. 
that Wal-Mart and TrafFix do not stand for the proposition that trade dress protection is unattainable for product design. In fact, these Supreme Court holdings arguably eased the finding of secondary meaning for the Eames chair by rejecting the lower court's decision to deny the plaintiff's trade dress claims based on the fact that the chair was not inherently distinctive. ${ }^{159}$

Instead, Wal-Mart and TrafFix opened the door to a reexamination of secondary meaning that turned out favorably for Herman Miller-particularly because, unlike the First and Seventh Circuits, ${ }^{160}$ the Sixth Circuit was willing to find secondary meaning in the absence of consumer surveys. ${ }^{161}$ The court also gave a generous interpretation to the background secondary meaning requirement that the trade dress serve a source-identifying function: while the general public did not associate the Eames chair with its manufacturer, the fact that "the consuming public in modern furniture" was well aware that Herman Miller made the Eames chair was held sufficient to establish secondary meaning in the product design. ${ }^{162}$

Herman Miller is a case in which the court applied a liberal interpretation of the secondary meaning factors, a process likely eased by the fact that the plaintiff had produced a deluge of evidence-the record contained more than five hundred pages. ${ }^{163}$ This was clearly a case in which the plaintiffs had studied, and learned from, the failures of other trade dress litigants.

\section{Defeating a Copycat: Coach, Inc. v. We Care Trading Co.}

In 2003, the Second Circuit affirmed a trade dress infringement case brought by the manufacturer of prestigious Coach handbags against a copycat who was selling knockoffs for pennies on the dollar. ${ }^{164}$ The Southern District of New York granted a permanent injunction (subsequently scaled back by the Second Circuit) ${ }^{165}$ to prevent the

${ }^{159} I d$. at 309-10. The Sixth Circuit rejected the district court's finding that Herman Miller's evidence for advertising and number of chairs sold was insufficient to satisfy the secondary meaning elements. Id. at 312-14.

${ }^{160}$ See supra Section VI.A.1 (discussing Yankee Candle and David White).

${ }^{161}$ Herman Miller, 270 F.3d at 315.

${ }^{162} I d$. at 316.

163 Id. at 302-03.

${ }^{164}$ Coach, Inc. v. We Care Trading Co., Nos. 01-7968, 01-9162, 2002 U.S. App. LEXIS 28143 (2d Cir. May 20, 2002).

${ }^{165}$ The Second Circuit held that the injunction, which had prevented We Care Trading Co. from selling all handbags made of "glove-tanned leather and bound 
infringer from copying any three of the following four design elements of Coach's "Classic Collection" handbags: "glove-tanned leather, bound edges, heavy brass or nickel-plated brass hardware, and a rectangular handbag with a beaded chain."166

The district court relied on Wal-Mart to define secondary meaning. ${ }^{167}$ The court also elaborated by quoting the Second Circuit's statement that " $[\mathrm{s}]$ econdary meaning existing where 'the public is moved in any degree to buy an article because of its source." ${ }^{168}$ To determine whether secondary meaning exists in the case of Coach handbags, the court applied six factors, a non-exhaustive list including “(1) advertising expenditures, (2) consumer studies linking the mark to a source, (3) unsolicited media coverage of the product, (4) sales success, (5) attempts to plagiarize the mark, and (6) length and exclusivity of the mark's use." 169 The court found that Coach had presented evidence to satisfy all six of these factors and was particularly persuaded by findings that the plaintiff had produced extensive customer surveys; that Coach had spent millions marketing its bags, which had been on the market for nearly forty years; and that its products had been plagiarized to the tune of 200,000 handbags a year, including some handbags manufactured by the defendant itself. ${ }^{170}$

The defendant's attempts to defeat the trade dress by showing that one or more of the protectable elements were functional did not succeed. Instead, the court stated that " $[t]$ he TrafFix decision does not overrule Second Circuit law that a collection of functional features may nonetheless be protectable trade dress."

In Coach, the Second Circuit's analysis was favorable to the plaintiff in one significant respect: the court was willing to accept a succinct description of the trade dress-far shorter and less detailed than

edges," was overbroad and added the requirement that the forbidden handbags also have "either the distinctive Coach hardware or its tag." Id. at *14.

${ }^{166}$ Robert T. Maldonado, Is that a Coach Bag? Product Configuration Trade Dress in the Second Circuit, INTELL. PROP. TODAY, July 2002, at 29.

167 The decision quotes Wal-Mart's definition of secondary meaning as existing where, "in the minds of the public, the primary significance of a [mark] is to identify the source of the product rather than the product itself." Coach, Inc. v. We Care Trade Co., 99-1 1672, 2001 U.S. Dist. LEXIS 9879, at *21 (S.D.N.Y. July 18, 2001) (quoting Wal-Mart Stores, Inc. v. Samara Bros., 529 U.S. 205, 211 (2000)).

${ }^{168}$ Id. (quoting Genesee Brewing Co. v. Stroh Brewing Co., 124 F.3d 137, 143 n.4 (2d Cir. 1997)).

${ }^{169}$ Id. at *21-22 (quoting Genesee Brewing Co., 124 F.3d at 143 n.4) (internal quotations omitted).

\footnotetext{
${ }^{170}$ Id. at *22.

${ }^{171}$ Id. at $* 27-28$.
} 
the lengthy nine-part description presented to the Sixth Circuit in Herman Miller. ${ }^{172}$ Perhaps even more relevant is a comparison to a case decided in the same circuit, GTFM, Inc. v. Solid Clothing, Inc., which, like Coach, also concerned trade dress of an entire collection of goods, rather than a single item (such as the Eames chair). ${ }^{173}$ In GTFM, the plaintiff was a manufacturer of upscale "hip-hop" clothing that had been copied by a competitor and sold at a discount. ${ }^{174}$ The trade dress infringement aspect of the suit failed because the court found that plaintiff's definition of its trade dress was "altogether too broad to be a protectable source-identifying expression." ${ }^{175}$

This outcome is somewhat surprising, considering that, unlike the facts in Yurman Design, plaintiff GTFM, Inc. had offered the court a lengthy and detailed six-part definition for each of its football and baseball jersey lines of clothing, elaborating on each set of elements including various subelements and specifying such details as the placement of patches and the types of colors in use. ${ }^{176}$ However, the court was unpersuaded by these efforts, finding that the definition did not show that "the overall look of its baseball and football jerseys is consistent across each of the product lines" ${ }^{177}$ and, thus, did not meet the requirement that a product line must have a consistent "overall look." While the Coach court also had to consider the defendant's argument that Coach's trade dress was impermissibly vague, it did not analyze whether an even higher level of specificity is required for trade dress in a collection of goods. ${ }^{179}$

${ }^{172}$ Herman Miller, Inc. v. Palazzetti Imps. \& Exps., Inc., 270 F.3d 298, 302 (6th Cir. 2001) (describing the trade dress of the Eames chair).

${ }^{179}$ GTFM, Inc. v. Solid Clothing, Inc., 215 F. Supp. 2d 273 (S.D.N.Y. 2002).

${ }^{174} I d$. at 277-78. All of the defendant's subsequent post-trial motions (to reconsider the injunction, to vacate, and to grant a new trial) have all been denied. See No. 01-2629, 2002 U.S. Dist. LEXIS 15422 (S.D.N.Y. Aug. 21, 2002) (denying motion for reconsideration), No. 01-2629, 2002 U.S. Dist. L.EXIS 24620 (S.D.N.Y. Dec. 27, 2002) (denying motions to vacate and for a new trial).

${ }_{175}$ GTFM, 215 F. Supp. 2d at 299 (quoting Yurman Design, Inc. v. PAJ, Inc., 262 F.3d 101, 118 (2d Cir. 2001)).

${ }^{176}$ Id. at $280-83$.

177 Id. at 299.

${ }^{178} I d$.

${ }^{179}$ Coach, Inc. v. We Care Trading Co, No. 99-11672, 2001 U.S. Dist. LEXIS 9879, at *17-18 (S.D.N.Y. July 18, 2001). 


\section{Product Design or Product Packaging: Sally Beauty Co. v. Beautyco, Inc.}

Sally Beauty Co. involves the issue of whether the courts must affirmatively distinguish product design and product packaging. ${ }^{180}$ In this case, the Tenth Circuit, displaying greater leniency than other circuits, did not make much of the distinction-to the advantage of the plaintiff Sally Beauty Co. This case illustrates the discretion that courts have to treat similar fact patterns quite differently.

The trade dress in dispute involved the packaging of a hair care product marketed by Sally Beauty. Specifically, the case involved the use of a bullet-shaped, white bottle with a flat, black cap; text on the product's label; and very similar product names. ${ }^{181}$ In its approach to the trade dress infringement claim, the court did not sever the color and shape of the bottle from the labeling; it simply considered the "total look" of the product. ${ }^{182}$ This analysis differs in procedure from Wal-Mart's approach to a product design case, which would automatically assume that the product design is descriptive and, therefore, require proof of secondary meaning. ${ }^{183}$ Instead, the court employed Wal-Mart's approach to product packaging and first determined whether the trade dress was descriptive. Once the court concluded that the trade dress was descriptive, it then required a showing of secondary meaning. ${ }^{184}$

To prove secondary meaning, Sally Beauty argued that it had "(1) a history of successful sales; (2) evidence of intentional copying by Beautyco; and (3) long use of the Sally Beauty trade dress." ${ }^{185}$ While the court mentioned that the Third and Sixth Circuits have also considered the volume of sales in considering secondary meaning and likelihood of confusion, ${ }^{186}$ it was satisfied by Sally Beauty's three factors and concluded that "a genuine issue of material fact exists whether Sally Beauty's trade dress has acquired distinctiveness." ${ }^{187}$ This

${ }^{180}$ Sally Beauty Co. v. Beautyco, Inc., 304 F.3d 964, 970 (10th Cir. 2002).

${ }^{181}$ Id.

${ }^{182}$ See id. at 977 (analyzing the trade dress based on the product's "overall image and appearance").

${ }_{185}$ Wal-Mart Stores, Inc. v. Samara Bros., 529 U.S. 205, 212 (2000).

${ }^{184}$ Sally Beauty, 304 F.3d at 977.

${ }^{185} I d$. at 978.

${ }^{186}$ Id. (citing Abercrombie \& Fitch Stores, Inc. v. Am. Eagle Outfitters, Inc., 280 F.3d 619, 640 n.14 (6th Cir. 2002); Checkpoint Sys., Inc. v. Check Point Software Techs., Inc., 269 F.3d 270, 283 n.10 (3d Cir. 2001)).

${ }^{187}$ Id. (footnote omitted). 
relatively low evidentiary burden offers hope for new market entrants who have not yet attained the volumes of sales that time-honored companies such as Coach and Herman Miller have established in decades of doing business. Moreover, compared to the outcome in Yankee Candle, ${ }^{188}$ this is another example of a trade dress owner prevailing in an infringement claim without any customer survey evidence.

\section{Customer Surveys and Deliberate Copying: Clicks Billiards, Inc. v. Sixshooters, Inc.}

In Clicks Billiards, ${ }^{189}$ the owner of a chain of pool halls complained that a competitor had allegedly copied the décor of his establishments. The circuit court reversed the lower court's grant of summary judgment, in part, based on the trade dress issue. ${ }^{190}$ In the secondary meaning discussion, the court focused its attention on just two particular types of evidence introduced by Clicks Billiards, Inc.: a customer survey ${ }^{191}$ and evidence of deliberate copying. ${ }^{192}$

Neither of these factors was without controversy at the district court level. The trial court found that the "survey is not without flaws," and "[p]ut bluntly, the survey is of little or no value" because the respondents offered vague responses to follow-up questions. ${ }^{193}$ On appeal, the circuit court, found that since the lower court had admitted the survey rather than excluding it as impermissibly flawed, "the survey admitted by the district court raises questions of material fact with respect to secondary meaning that may not be disposed of by the court alone." ${ }^{194}$ Therefore, these were matters to be decided by a jury, which precluded a finding of summary judgment against Clicks Billiards. ${ }^{19}$

The plaintiff got similarly favorable treatment by the court of appeals on the issue of evidence of copying. The district court had found that testimony and affidavits suggesting that Sixshooters, Inc.'s owners had visited Clicks Billiards on numerous occasions and had

${ }^{188}$ See supra notes 115-122 and accompanying text (describing the First Circuit's analysis of the lack of secondary meaning owing to the plaintiff's failure to produce consumer surveys).

${ }^{189} 251$ F.3d 1252, 1256 (9th Cir. 2001).

${ }^{190} I d$. at 1267.

${ }^{191}$ Id. at $1262-64$.

${ }^{192}$ Id. at 1264.

${ }^{193} I d$. at 1262-63.

${ }^{194} I d$. at 1264 .

${ }^{195} \mathrm{Id}$. 
even measured the fixtures in Clicks was, in total, "slight" and "contested." 196 In contrast, the Ninth Circuit held that such an evaluation precluded a finding of summary judgment, since "the district court is prohibited from weighing evidence and deciding issues of contested fact." ${ }^{197}$ Aside from this evidence of intentional copying and the consumer survey results, however, the Ninth Circuit did not demand a further showing of other factors tending to support a finding of secondary meaning.

\section{CONCLUSION}

To paraphrase Mark Twain, reports of the death of product design trade dress claims have been greatly exaggerated. ${ }^{198}$ Though, as we have seen, cases in which product design owners succeeded in proving secondary meaning may be few in number, their very existence confirms what one observer stated in regard to Herman Miller: "Although product design trade dress claims may be on life support, this case shows they're not totally dead yet."199

The nature of the products at issue in the "successful" cases may give some indication of factors likely to persuade to a court considering secondary meaning. For instance, the products protected in Herman Miller and Coach are exclusive, highly marketed, and broadly recognized. These characteristics place such products in a privileged position with respect to proving secondary meaning. Indeed, in an article discussing the litigation, the Coach attorney observed that dicta in a 2000 decision involving the French luxury accessory manufacturer Hermès, Int'l "paved the way for the affirmance received by Coach for its handbags," since the Hermès court "noted that plaintiff's heavily marketed handbags "continue to indicate their source."”200 Similarly, watch and jewelry manufacturer Cartier won a preliminary injunction against a manufacturer who had copied its Pasha and Grille design

196 Id.

197 Id.

${ }^{198}$ The Twain quotation is from an 1897 letter in which he wrote that "the report of my illness grew out of [another man's] illness, this report of my death was an exaggeration." See Letter from Mark Twain (May 1897), in Barbara Schmidt, Mark Twain Quotations, Newspaper Collections, $\mathcal{E}$ Related Resources, at http://www.twainquotes.com/ Death.huml (last visited Mar. 14, 2004).

${ }^{199}$ Barber, supra note 114, at 259 (discussing Herman Miller, Inc. v. Palazetti Imports $\mathcal{E}^{2}$ Exports, Inc., 270 F.3d 298 (6th Cir. 2001)).

${ }^{200}$ Maldonado, supra note 166 , at 30 n.25 (quoting Hermes Int'l v. Lederer de Paris Fifth Ave., Inc., 219 F.3d 104, 110 (2d Cir. 2000)). 
watches. ${ }^{201}$ In finding acquired distinctiveness, the court praised as "a fine example of secondary meaning...'the world-renown Cartier brand[,] ... . [noting it is] instantly identifiable ... by even the most lightweight watch lover."

Yet, exclusivity and international recognition cannot explain everything; otherwise, the expensive and heavily marketed jewelry at issue in Yurman Design ${ }^{203}$ would have shown secondary meaning. Conversely, the low-cost shampoos and conditioners that proved secondary meaning in Sally Beauty ${ }^{204}$ might not have met the required evidentiary burden. Further, had the Ninth Circuit found global or national recognition necessary to a finding of secondary meaning in the new, postWal-Mart world, it might have considered Clicks Billiards differently since the case concerned a small regional chain of billiard halls in the Southwest and a competitor with a single establishment. ${ }^{205}$

Aside from the perhaps unexpected persistence of product design claims after Wal-Mart, the recent cases point to a storm brewing on the horizon: the growing inconsistencies in the factors by which the various circuits evaluate secondary meaning. Wal-Mart may have settled the quarrel in the circuits over the old inherent-distinctiveness test, but the Supreme Court will likely soon have to take up the matter of distinctiveness in product design to define the appropriate criteria for secondary meaning. The secondary meaning factor that seems most obviously in flux at the moment is the consumer-survey requirement. Survey evidence was deemed essential by the First Circuit, which called it the "'preferred' manner of demonstrating secondary meaning." Yet, the Tenth Circuit found secondary meaning entirely absent of consumer surveys in Sally Beauty, ${ }^{207}$ and the Ninth Circuit considered even flawed surveys to benefit the trade dress owner in Clicks Billiards. $^{208}$

${ }^{201}$ Cartier, Inc. v. Four Star Jewelry Creations Inc., No. 01 11295, 2003 U.S. Dist. LEXIS 7844, at *4 (S.D.N.Y. May 8, 2003).

${ }^{202}$ Id. at $* 25-26$ (citing Rudiger Bucher, Comparative Test: Chronos with the Frederic Piguet Caliber 1185, WATCHTime (June 2001)).

${ }^{203}$ Yurman Design, Inc. v. PAJ, Inc., 262 F.3d 101, 107 (2d Cir. 2001).

${ }^{204}$ Sally Beauty Co. v. Beautyco, Inc., 304 F.3d 964, 970 (10th Cir. 2002).

${ }^{205}$ Clicks Billiards, Inc. v. Sixshooters, Inc., 251 F.3d 1252, 1256 (9th Cir. 2001).

${ }^{206}$ Yankee Candle Co. v. Bridgewater Candle Co., 259 F.3d 25, 39 (1st Cir. 2001)

(citing Boston Beer Co. v. Slesar Bros. Brewing Co., 9 F.3d 175, 182 (1st Cir. 1993)).

207 Sally Beauty, 259 F.3d at 978.

${ }^{208}$ Clicks Billiards, 251 F.3d at 1262-63. 
Wal-Mart asserted that pleading inherent distinctiveness is "not worth the candle." ${ }^{209}$ After Wal-Mart eliminated inherent distinctiveness for product design cases, the action now has turned to whether, and how, trade dress owners can meet the sometimes substantial evidentiary burden of proving that the design has acquired the necessary secondary meaning to show distinctiveness.

The broader policy question raised by this shift is the degree to which the courts can or will protect the product designs of new market entrants. Secondary meaning tests, in all their various guises, favor established players, since in every case the purpose of the secondary meaning inquiry is to determine whether the trade dress serves a source-identifying function. The Supreme Court argued against an inherent-distinctiveness test in Wal-Mart partly because such a test could hurt new entrants by making them vulnerable to strike suits. ${ }^{210}$ Now the question is whether the evidentiary burden of secondary meaning, and the inconsistency with which the matter is treated across circuits, will have the same detrimental effect on the competitive ability of trade dress owners to protect their product designs.

${ }^{209}$ Wal-Mart Stores, Inc. v. Samara Bros., 529 U.S. 205, 214 (2000).

${ }^{210}$ See id. at 213 ("Consumers should not be deprived of the benefits of competition with regard to the utilitarian and esthetic purposes that product design ordinarily serves by a rule of law that facilitates plausible threats of suit against new entrants based upon alleged inherent distinctiveness."). 


\section{APPENDIX}

\section{Table 1: Types of Secondary Meaning Evidence Presented By Plaintiffs in Trade Dress Infringement Claims}

\begin{tabular}{|c|c|c|c|c|c|c|c|c|}
\hline & Surveys ${ }^{1}$ & Testimony ${ }^{2}$ & Use $^{3}$ & Advert. ${ }^{4}$ & Sales $^{5}$ & Estab. & $\begin{array}{l}\text { Intent. } \\
\text { Copy }^{7}\end{array}$ & Other \\
\hline $\begin{array}{l}\text { Yankee } \\
\text { Candle }^{8}\end{array}$ & & $X^{9}$ & $\mathrm{x}$ & $\mathrm{X}$ & $\mathrm{x}$ & $\mathrm{x}$ & $\mathrm{X}$ & \\
\hline $\begin{array}{l}\text { Yurman } \\
\text { Design }^{10}\end{array}$ & & & & & & & & \\
\hline Coach & $\mathrm{x}$ & & $\mathrm{x}$ & $\mathrm{x}$ & $\mathrm{X}^{11}$ & & $\mathrm{X}$ & $x^{12}$ \\
\hline $\begin{array}{l}\text { Herman } \\
\text { Miller }^{8}\end{array}$ & & $\mathrm{X}$ & $\mathrm{x}$ & $\mathrm{x}$ & $\mathrm{X}$ & $\mathrm{x}$ & $\mathrm{X}$ & \\
\hline $\begin{array}{l}\text { Echo } \\
\text { Travel } \\
\end{array}$ & $\mathrm{x}$ & $\mathrm{x}$ & $\mathrm{x}$ & $\mathrm{x}$ & $\mathrm{x}$ & $\mathrm{x}$ & $\mathrm{X}$ & \\
\hline $\begin{array}{l}\text { Clicks } \\
\text { Billards }\end{array}$ & $\mathrm{x}$ & & & & & & $\mathrm{x}$ & \\
\hline $\begin{array}{l}\text { Sally } \\
\text { Beauty }\end{array}$ & & & $\mathrm{X}$ & & $\mathrm{x}$ & & $\mathrm{X}$ & \\
\hline $\begin{array}{l}\text { David } \\
\text { White }^{8}\end{array}$ & & $\mathrm{X}$ & $\mathrm{x}$ & $X^{19}$ & $\mathrm{X}$ & $\mathrm{x}$ & $\mathrm{X}$ & \\
\hline
\end{tabular}

Consumer surveys

Consumer testimony

${ }^{3}$ Long and exclusive use of mark

4 Advertising amount and manner

${ }^{5}$ Amount of sales and number of customers

${ }^{6}$ Established place in the market

${ }^{7}$ Proof of intentional copying

${ }^{8}$ Court referenced lack of surveys provided by party

${ }^{9}$ Employee or competitor testimony used by party

${ }^{10}$ Decision not reached because definition provided by party was inadequate

${ }^{11}$ Required "sales success" of party

${ }^{12}$ Discussed unsolicited media coverage

${ }^{13}$ Court referenced advertised functional features 
Table 2: Success of Plaintiffs in Trade Dress Infringement Claims Based on Evidence Presented

\begin{tabular}{|c|c|c|}
\hline Court & Case & Result \\
\hline First Circuit & Yankee Candle & Fail \\
\hline Second Circuit & Yurman Design & Fail \\
\hline Second Circuit & Coach & Pass \\
\hline Sixth Circuit & Herman Miller & Pass \\
\hline Seventh Circuit & Echo Travel & Pass \\
\hline Ninth Circuit & Clicks Billiards & Pass \\
\hline Tenth Circuit & Sally Beauty & Pass \\
\hline Eastern District of Illinois & David White & Fail \\
\hline
\end{tabular}


* $* * * * *$ 